\title{
PENGEMBANGAN LEMBAR KERJA SISWA (LKS) MATERI MENULIS TEKSEKSPOSISI DENGAN TEKNIK COPY THE MASTERSISWA KELAS X SMK KARTIKA 1-2 PADANG
}

\author{
Oleh: \\ Ade Yulia Ningsih ${ }^{1}$, Syahrul R ${ }^{2}$, Ena Noveria ${ }^{3}$ \\ Program Studi Pendidikan Bahasa dan Sastra Indonesia \\ FBS Universitas Negeri Padang \\ email: adeyulianingsih45@gmail.com
}

\begin{abstract}
This study aims to (1) describe the process of developing LKS with copy the master technique for learning to write valid exposition text, (2) practical and (3) effective. The development mode used is 4-D model consisting of 4 stages, namely define, design, development . This development process produces products in the form of LKS with copy the master technique for expository, valid, and effective expository writing material.The results of this study indicate that the resulting LKS categorized as valid, effective and practical. It is seen based on the value of validity, practicality and effectiveness of LKS. The overall LKS validity score is $77.15 \%$, the average of practicality by teachers is $85 \%$ and the student is $83.33 \%$ ) and effective.Based on the calculation with Likert formula obtained $85.25 \%$ results so that the use of LKS model with copy the master technique on writing material exposition effectively.
\end{abstract}

\section{A. Pendahuluan}

Kata kunci: pengembangan , LKS, menulis teks eksposisi, teknik copy the master, validitas, efektivitas, praktikalitas

Keterampilan menulis teks eksposisi merupakan salah satu pembelajaran yang dituntut dalam kurikulum KTSP pada mata pelajaran bahasa Indonesia bagi siswa SMA/SMA sederajat. Menurut Gestein dan Baker (2011), pembelajaran keterampilan menulis teks eksposisi merupakan salah satu pembelajaran yang sulit bagi banyak siswa usia sekolah menengah. Teks eksposisi adalah teks yang menjelaskan berbagai hal (Barry, 2010). Siswa dapat mengalami kesulitan menuliskan informasi, paragraf dan esai. Dalam menulis teks eksposisi siswa sering mengalami kesalahan dalam ejaan dan komposisi penulisan teks. Salah satu faktor yang menyebabkan rendahnya keterampilan menulis siswa adalah teknik pembelajaran dan penggunaan bahan ajar yang belum maksimal.

Teknik pembelajaran dan bahan ajar sangat berpengaruh terhadap hasil belajar siswa. Guru hendaknya bisa memilih teknik pembelajaran yang bervariasi, salah satunya adalah teknik copy the master. Menurut Maharimin (2009) teknik copy the master mencontoh kerangka atau ide bahkan juga cara atau teknik. Pada dasarnya teknik ini menuntut untuk melakukan latihanlatihan sesuai dengan model yang ditawarkan.

\footnotetext{
${ }^{1}$ Mahasiswa penulis Skripsi Prodi Pendidikan Bahasa Indonesia untuk wisuda periode September 2018

2 Dosen Bahasa Indonesia FBS Universitas Negeri Padang

${ }^{3}$ Dosen Bahasa Indonesia FBS Universitas Negeri Padang
} 
Berdasarkan beberapa penelitian penggunaan teknik copy the master dapat meningkatkan hasil belajar siswa. Hal itu dibuktikan dengan penelitian yang dilakukan oleh Harlina(2016), Rohimat (2013), Zurita (2017) serta peneliian Rosyidah, Syahrul dan Ermanto (2013) yang telah menguji teknik copy the master yang berdampak positif kepada siswa.

Bahan ajar merupakan salah satu komponen pembelajaran. Bahan ajar dapat dibuat dalam berbagai bentuk sesuai dengan kebutuhan dan karakteristik materi ajar yang akan disajikan. Salah satu cara yang digunakan yaitu mengembangkan bahan ajar. Bahan ajar yang dikembangkan sendiri oleh guru dapat disesuaikan dengan tuntutan kurikulum, tuntutan karakteristik sasaran, dan tuntutan pemecahan masalah. Jadi, dengan tersedianya bahan ajar yang bervariasi, guru akan lebih mudah melaksanakan pembelajaran dan kegiatan pembelajaran akan lebih menarik bagi siswa.

Bahan ajar yang dapat dikembangkan guru, di antaranya adalah lembar kerja siswa (LKS).LKS merupakan bahan ajar cetak berupa lembar-lembar kertas yang berisi materi, ringkasan, dan petunjuk-petunjuk pelaksanaan tugas pembelajaran yang mengacu pada kompetensi dasar yang harus dicapai (Prastowo, 2011:204).LKS merupakan stimulus atau bimbingan guru dalam pembelajaran yang akan disajikan secara tertulis sehingga dalam penulisannya perlu memperhatikan kriteria media grafis sebagai media visual untuk menarik perhatian peserta didik. Paling tidak LKS sebagai media kartu. Sedangkan isi pesan LKS harus memperhatikan unsur-unsur penulisan media grafis, hirarki materi dan pemilihan pertanyaanpertanyaan sebagai stimulus yang efisien dan efektiv (Hidayah, 2007:8). Melalui LKS guru menyuruh siswa untuk menjawab soal-soal yang telah tersedia setelah menaikkan materi pokok tertentu baik secara personal maupun kelompok.

LKS yang dibutuhkan siswa adalah LKS yang menarik, bagus, dan bermanfaat sehingga dapat menimbulkan minat siswa untuk menggunakan LKS dalam proses pembelajaran, salah satunya dalam penulisan teks eksposisi. Pembelajaran menulis teks eksposisi dalam Kurikulum KTSP kelas X SMK semester satu dengan kopetensi dasar (KD) 4.2 memproduksi teks eksposisi baik lisan maupun tulisan.

Berdasarkan hasil wawancara dengan salah seorang guru mata pelajaran bahasa Indonesia kelas X SMK Kartika 1-2 Padang, Ibu Erfina Dewita, S. Pd., pada tanggal 18 Desember 2013 diperoleh informasi bahwa terdapat beberapa faktor yang menjadi masalah pembelajaran menulis teks eksposisi. Pertama, perolehan nilai siswa yang tidak memenuhi Kriteria Ketuntasan Minimal (KKM) yang ditetapkan yaitu 80. Kedua, kurang menariknya media yang digunakan dalam proses pembelajaran menulis teks ekspositoris. Guru masih menggunakan metode belajar tradisional yaitu ceramah yang membuat siswa merasa bosan dalam belajar. Ketiga, dalam proses pembelajaran, siswa tidak menggunakan LKS sebagai bahan ajar alternatif untuk meningkatkan kemampuan menulis siswa. Berdasarkan fenomena tersebut, pengembangan Lembar kerja Siswa (LKS) perlu dilakukan. Peneliti berharap, dengan penggunaan LKS yang dilengkapi dengan teknik pemodelan, siswa akan mahir dan dapat meningkatkan keterampilan menulis teks eksposisi.

Berdasarkan uraian tersebut, bahan ajar untuk keterampilan menulis teks perlu dikembangkan, dan penulis memfokuskan kepada keterampilan menulis teks eksposisi siswa kelas X SMK Kartika 1-2 Padang dengan menggunakan teknik copy the master.Santoso (2003) mengemukakan bahwa dalam pelaksanaan teknik copy the master ada beberapa langkah yang harus dilakukan di kelas, yaitu (1) model yang dipilih guru dibaca bersama-sama di dalam kelas, (2) baca juga analisisi model (setiap model disertai dengan sedikit analisis mengenai bagus atau tidaknya tulisan itu dan menelusuri jalan pikiran penulis ketika menciptakan model, (3) guru mrngajak siswa memikirkan objek-objek lain yang kira-kira dapat dituliskan dengan menggunakan pola, gaya atau cara-cara yang dipakai dalam model itu, (4) siswa menuliskan idenya yang sejalan dengan model yang dibahas dan (5) kumpulkan tugas siswa.

Berdasarkan uraian tersebut, LKS materi menulis teks eksposisi kelas X SMK Kartika 1-2 Padang perlu dikembangkan. Penulis mengembangkan LKS materi keterampilan menulis teks eskposisi kelas $\mathrm{X}$ dengan menggunakan teknik copy the master yang valid, efektif dan praktis. 


\section{B. Metode Penelitian}

Jenis penelitian ini adalah penelitian pengembangan (research and development) karena menghasilkan produk. Menurut Gay (2009) R\&D adalah penelitian yang menggabungkan riset dan pengembangan serta menghasilkan produk. Produk yang dihasilkan dapat berupa produk baru atau menyempurnakan produk yang sudah ada. Dalam penelitain ini, produk yang dihasilkan merupakan produk baru berupa LKS pada materi menulis teks eksposisi kelas X SMK Kartika 1-2 Padang.

LKS dengan teknik copy the master ini dikembangkan dengan 4-D models. Ada 4 tahap dalam 4-D models yaitu define (definisi), design (desain), develop (pengembangan) dan dissemaninate (penyebaran). Dalam tahap define dilakukan penetapan dan pendefinisian syarat-syarat pembelajaran. Melalui analisisi ditentukan tujuan dan kendala untuk materi pembelajaran. Langkah-langkah yang dilaksanakan pada tahap define adalah analisis awal akhir, analisis siswa, analisis tugas, analis konsep dan tujuan pembelajaran.

Tahap selanjutnya adalah tahap design. Kegiatan yang dilakukan pada tahap ini adalah mendesain prototipe LKS yang dikembangkan. Kegiatan pad tahap ini dapat dilakukan setelah menentukan tujuan pembelajaran untuk pengembangan model LKS menggunakan teknik copy the master. Langkah-langkah pada tahap ini adalah pemilihan media, pemilihan format dan desian awal. Tahap ketiga adalah tahap develop. Tahap ini bertujan untuk merevisi prototipe media (LKS) yang telah dihasilkan pada tahap sebelumnya. Tahap ini adalah tahap merevisi LKS sebelum menjadi versi akhir yang efektif oleh ahli. Langkah-langkah pada tahap develop adalah penilain ahli dan uji pengembangan.

Uji coba produk dilakukan dengan tujuan mengetahui kelayakan produk (valid), kevalidan produk dilakukan oleh ahli yakni dosen Pendidikan Bahasa dan Sastra Indonesia Fakultas Bahasa dan Seni Universitas Negeri Padang dan guru Bahasa Indonesia SMK Kartika 1-2 Padang. Kepraktisan produk didapat melalui uji praktikalitas oleh guru Bahasa Indonesia dan siswa. Keefektivan produk didapat melalui uji efektifitas yang diberikan kepada guru dan siswa. Dalam penelitian ini, produk yang diujicobakan adalah model LKS menggunakan teknik copy the master pada materi menulis teks eksposisi siswa kelas X SMK Kartika 1-2 Padang yang telah dikembangkan.

Subjek uji coba produk LKS menggunakan teknik copy the master pada materi menulis teks eksposisi adalah siswa kelas X SMK Kartika 1-2 Padang dengan jumlah sampel 20 orang siswa. Jenis data pada penelitian ini adalah data primer., uji praktikalitas dan hasil belajar siswa. Instrumen pengumpulan data yang digunakan adalah angket validitas, angket praktikalitas, dan instrumen keefektifan berupa lembaran pengamatan aktivitas dalam pembelajaran dan tes hasil belajar.

Setelah data uji validitas, uji praktikalitas dan uji efektivitas terkumpul, langkah selanjutnya adalah menganalisis data penelitian melalui tahap-tahap berikut. Pertama, menganalisis hasil uji validitas model LKS menggunakan teknik copy the master. Analisis validasi LKSdiperoleh melalui angket validitas yang terdiri dari empat aspek yaitu kelayakan isi, kelayakan penyajian, kelayakan bahasa dan kegrafikan LKS. LKS dinilai oleh validator menggunakan skala Likers. Hasil pengolahan tersebut berupa data kualitatif yang mendeskripsikan tingkat validitas LKS yang dirancang. Kedua, menganalisis hasil uji praktikalitas LKS.Setelah itu, dilakukan pengelompokan sesuai kriteria antara lain sangat praktis, praktis, cukup praktis, kurang praktis atau tidak praktis.

Ketiga, menganalisis hasil uji efektivitas LKS. Efektifitas diketahui melalui hasil belajar siswa dalam ranah kognitif. Hasil belajar siswa dalam ranah kognitif digunakan untuk mengukur tingkat ketuntasan belajar siswa. Setelah didapatkan data uji efektivitas, data tersebut dikelompokkan menjadi 5 kategori yaitu Sangat Efektif, Efektif, Kurang efektif dan Tidak Efektif. 


\section{Pembahasan}

\section{Tahap Define (Pendefinisian)}

\section{a. Analisis Awal Akhir}

Analisis awal akhir bertujuan untuk mempelajari dan menetapkan masalah dasar yang dihadapi siswa dalam proses pembelajaran. Kemudian dicari alternatif untuk pemecahan masalah tersebut.

\section{b. Analisis Siswa}

Analisis siswa dilakukan melalui pengamatan terhadap siswa kelas X SMK Kartika 1-2 Padang. Berdasarkan rekapitulasi data siswa kelas yang diperoleh dari TU, siswa yang duduk di kelas X umumnya lahir pada tahun 1998-1999. Dengan kata lain, rata-rata siswa berusia 16-17 tahun dan berada pada tahap operasi formal.. Pada tahap ini, seorang anak sudah dapat berfikir secara abstrak dan logis. Selain itu, siswa sudah termasuk kedalam kategori individu yang telah mampu mengembangkan potensi psikomotor sehingga terampil dalam penggunaan bahan ajar.

\section{c. Analisis Tugas}

Analisis tugas dilakukan dengan menganalisis kemampuan yang harus dikuasai siswa seperti Standar Kompetensi (SK), Kompetensi Dasar (KD) dan Indikator. Standar kompetensi (SK) yang dimaksud berbunyi "Berkomunikasi dengan Bahasa Indonesia setara tingkat semenenja." Berdasarkan SK tersebut diturunkan Kompetensi Dasar (KD) yang berbunyi "Membuat berbagai teks tertulis dalam konteks bermasyarakat dengan memilih kata, bentuk kata dan ungkapan yang tepat".Selanjutnya, Kompetensi Dasar tersebut dijabarkan menjadi indikator berikut ini.
a) Mampu menjelaskan pengertian karangan
b) Mampu menjelaskan pengertian karangan eksposisi
c) Mampu menentukan ciri-ciri karangan eksposisi
d) Mampu menjelaskan jenis-jenis karangan eksposisi
e) Mampu menjelaskan struktur karangan eksposisi
f) Mampu menentukan langkah-langkah menulis karangan eksposisi
g) Mampu menyusun kerangka karangan eksposisi berdasarkan tema yang telah ditentukan
h) Mampu mengembangkan kerangka karangan eksposisi

\section{d. Analisis Konsep}

Berdasarkan SK, KD, dan Indikator tersebut, dapat diidentifikasi konsep-konsep utama yang terdapat pada materi menulis karangan eksposisi. Konsep-konsep tersebut, yaitu pengertian karangan, pengertian karangan eksposisi, ciri-ciri karangan eksposisi, jenis-jenis karangan eksposisi, langkah-langkah menulis karangan eksposisi, menyusun kerangka karangan eksposisi berdasarkan tema yang telah ditentukan, dan mengembangkan kerangka karangan eksposisi.

\section{e. Analisis Tujuan Pembelajaran}

Berdasarkan analisis tugas dan analisis konsep, dihasilkan tujuan pembelajaran yang menjadi dasar untuk mengkonstruksi bahan ajar yang dikembangkan.Tujuan pembelajaran yang terdapat dalam model LKS yang dikembangkan adalah sebagai berikut. Setelah membaca materi pembelajaran di rumah dan bertanya jawab, siswa mampu menjelaskan pengertian karangan, pengertian karangan eksposisi, ciri-ciri karangan eksposisi dan jenisjenis karangan eksposisi, mampu menjelaskan pola pengembangan, mampu menentukan langkah-langkah menulis karanagan eksposisi, mampu menyususn karangan eksposisi dan mengembangkan karangan dengan tepat. 


\section{Tahap Design (Perancangan) \\ a. Pemilihan Media}

Setelah tahap definedilakukan, tahap berikutnya adalah pemilihan teknik yang sesuai. Teknik yang dipilih untuk model LKS adalah teknik copy the master dan materi dirangkum secara ringkas dengan kalimat sederhana sehingga mudah dipahami siswa.. Selain itu, dalam LKS juga terdapat refleksi diri yang berfungsi mengukur dan mengetahui kemampuan siswa b. Pemilihan Format

Pemilihan format dilakukan dengan menentukan komponen-komponen yang terdapat dalam LKS.Komponen-komponen dalam LKS, yaitu kata pengantar, daftar isi, petunjuk penggunaan LKS, rangkuman materi disertai SK, KD, indikator, dan tujuan pembelajaran, latihan, lembar kerja siswa, refleksi diri, dan kepustakaan.

\section{c. Desain Awal}

Desain awal dilakukan dengan pembuatan contoh karangan eksposisi yang akan di tiru kerangka dan strukturnya, penelaahan, dan pengeditan LKS yang sudah dirancang. Apabila masih terdapat bagian yang belum sesuai, dilakukan pengeditan pada setiap komponen LKS.

LKS dengan teknik copy the master dicetak timbal balik. Kemudian, setiap halaman LKS diberi nomor halaman, kecuali cover.Nomor halaman terletak di bagian tengah bawah.Halaman kata pengantar, daftar isi, dan petunjuk penggunaan LKS menggunakan angka 1 - 6 secara berurutan.Untuk halaman selanjutnya diguanakan angka $3-30$.

Jenis dan ukuran huruf harus disesuaikan dengan keterbacaan dan kejelasan isi dari LKS.Jenis tulisan yang digunakan dalam LKS adalah Kristen ITC.Ukuran huruf yang digunakan untuk judul $14 \mathrm{pt}$ dan untuk isi $12 \mathrm{pt}$.

Desain setiap komponen LKS harus menarik, seperti pemberian warna, pemilihan jenis tulisan dan ukuran huruf serta pemilihan gambar untuk LKS.Komponen LKS pertama yang harus di desain adalah cover.Bagian cover LKS memuat identitas LKS yang meliputi judul materi pokok, sasaran penggunaan, dan nama validator. Bagian cover dibuat dengan menggunakan Microsoft Word 2007 dengan background yang didominasi warna putih.Cover menggunakan jenis huruf dan warna huruf yang sama tetapi ukuran huruf berbeda-beda. Jenis huruf yang digunakan dalam coveradalah Comic Sans Msdengan warna huruf hitam dan warna background yang kontras.Ukuran huruf yang digunakan dalam cover adalah ukuran huruf yang jelas dibaca

Selanjutnya, dilakukan desain pada halaman pertama LKS, yaitu kata pengantar.Kata pengantar berisi ucapan syukur penulis kepada Tuhan Yang Maha Esa dan ucapan terima kasih kepada pihak yang telah membantu dalam penyusunan LKS.Halaman LKS selanjutnya adalah daftar isi yang memuat daftar halaman-halaman yang menyusun LKS.Dalam daftar isi ditampilkan gambar halaman-halaman penting seperti halaman petunjuk penggunaan LKS, rangkuman materi, latihan, refleksi diri. Tujuan ditampilkan gambar masing-masing halaman adalah untuk menarik minat siswa membaca LKS.

Petunjuk penggunaan LKS terletak setelah daftar isi. Petunjuk penggunaan LKS berfungsiuntuk memberitahukan kepada pembaca tentang petunjuk umum bagian-bagian LKS, petunjuk komik strip, petunjuk untuk guru dan siswa. Berikut ini tampilan halaman petunjuk penggunaan LKS.Halaman LKS selanjutnya adalah rangkuman materi. Dalam rangkuman materi dijelaskankonsep-konsep dasar tentang karangan eksposisi dengan kalimat yang jelas dan mudah dipahami siswa. Latihan dalam LKS terletak setelah rangkuman materi.Latihan berisi soal-soal essay yang berfungsi untuk mengukur pemahaman siswa tentang materi yang dipelajari.Soal dan lembar jawaban terletak di halaman berbeda.Tujuannya agar ada ruang pengisisan jawaban dari latihan yang diberikan sehingga siswa tidak mengalami kesulitan dalam menjawab pertanyaan.

Halaman selanjutnya adalah contoh karangan eksposisi disertai dengan analisis struktur dan kebahasaan karangan eksposisi.Berikut tampilan contoh karangan eksposisi dan analisis struktur dan kebahasaannya.Halaman LKS selanjutnya adalah lembar kerja 
siswa.Lembar kerja siswa berupa lembar jawaban kosong yang berfungsi untuk mengisi hasil jawaban siswa dari latihan dalam LKS yang diberikan.Di akhir pertemuan, diberikan refleksi diri dalam LKS dengan tujuan untuk mengukur dan mengetahui kemampuan siswa terhadap keterampilan menulis.Siswa memilih pilihan yang disediakan dari tiap pernyataan sesuai dengan perbuatan yang telah dilakukan sehari-hari.Setelah halaman Refleksi Diri, di halaman akhir dilampirkan kepustakaan.

\section{Tahap Develop (Pengembangan) \\ a. Uji Validitas LKS}

Uji validitas LKS dilakukan oleh satu orang dosen jurusan Bahasa dan Sastra Indonesia, Fakultas Bahasa dan Seni (FBS) UNP dan satu orang guru Bahasa Indonesia SMK Kartika 12 Padang dengan menggunakan angket validitas. Proses validasi dilakukan dengan memberikan angket dengan total 29 butir pernyataan dengan pembagian sebagai berikut. Pada penilaian kelayakan isi terdapat 10 butir pernyataan.Pada penilaian kebahasaan terdapat 7 butir pernyataan.Pada peniliaian penyajian LKS terdapat 8 butir pernyataan.Pada penilaian kegrafikan terdapat 4 butir pernyataan. Masing-masingbutir pernyataan menggunakan skala Likert dengan 4 alternatif jawaban yaitu sangat setuju (SS) dengan skor 4, setuju (S) dengan skor 3, tidak setuju (TS) dengan skor 2 dan sangat tidak setuju (STS) dengan skor 1. Dari penilaian validator diperoleh hasil bahwa LKS dengan teknik copy the master valid dengan tingkat kevalidan 77,15 \%.

\section{b. Uji Praktikalitas LKS}

Uji praktikalitas LKS dilakukan kepada 20 orang siswa kelas X.SMK Kartika 1-2 Padang dan satu orang guru Bahasa Indonesia kelas X SMK Kartika 1-2 Padang. Data praktikalitas guru diperoleh melalui pengisian angket penilaian praktikalitas oleh guru sedangkan data praktikalitas siswa diperoleh melalui pengisian angket penilaian praktikalitas oleh siswa. Dari uji praktikalitas diperoleh hasil bahwa LKS yang dikembangkan praktis dengan nilai rata-rata praktikalitas LKS 83,09\%. Selain guru, uji praktikalitas juga dilakukan kepada 20 orang siswa kelas X. SMK Kartika 1-2 Padang.Data praktikalitas dari siswa diperoleh melalui pengisian angket praktikalitas.Hasil uji praktilakitas siswa dapat disimpulkan bahwa LKS yang dikembangkan praktis dengan nilai rata-rata praktikalitas LKS 83,2\%.

\section{c. Uji Efektivitas LKS}

Uji efektivitas dilakukan dengan cara memberikan pretest kepada 20 orang siswa kelas X SMK Kartika 1-2 Padang. Tujuan pemberian pretest untuk mengukur keterampilan menulis karangan eksposisi siswa sebelum diberikan model LKS dengan teknik copy the master .Tes yang diberikan berbentuk soal uraian dan di dalam soal tersebut siswa ditugaskan menulis sebuah karangan eksposisi dengan ketentuan yang telah ditetapkan.

Setelah dilakukan pretest, pertemuan berikutnya siswa belajar dengan menggunakan model LKS dengan teknik copy the master. Untuk melihat dan mengetahui kemampuan siswa dalam menulis karangan eksposisi setelah belajar dengan model LKS dengan teknik copy the master., Pada pertemuan terakhir siswa diberikan posttest. Soal yang diberikan sama dengan soal pretest. Hasil nilai pretest dan posttest siswa akan menunjukkan keefektifan model LKS dengan teknik copy the master yang digunakan siswa dalam proses pembelajaran. mencari keefektivan LKS dilakukan dengan cara, Pertama mencari mean pretest. Didapatkan mean pretest adalah 51,75. Kedua, mencari mean posttest. Mean dari posttest adalah 85,25\%. Ketiga mencari keefektifan LKS dengan teknik Copy the Master. Didapatkan hasil 82,25\% dengan sebutan sangat efektif.

\section{Kesimpulan dan Saran}

Berdasarkan hasil penelitian yang telah dilakukan, diperoleh kesimpulan bahwa LKS dengan teknik copy the master pada materi menulis teks eksposisi siswa kelas X SMK Kartika 1-2 Padang dikembangkan dengan menggunakan 4-D models, yaitu define (definisi), design (desain), 
develop (pengembangan) dan dissemainate (penyebaran). Namun, mengingat keterbatasan waktu dan biaya, penelitian ini dilakukan sampai tahap develop (pengembangan) saja.

Selanjutnya, dari ketiga tahap tersebut telah dihasilkan Lembar Kerja Siswa (LKS) dengan teknik copy the master pada materi menulis karangan eksposisi siswa kelas X SMK Kartika 1-2 Padang yang valid, (rata-rata validitas sebesar 77,15\%), praktis (rata-rata praktikalitas oleh guru sebesar $85 \%$ dan siswa sebesar 83,33\%) dan efektif. Keefektifan LKS dengan teknik copy the master dapat diketahui dari hasil belajar ranah kognitif sisiwa.

Hasil belajar ranah kognitif siswa diperoleh dari pretest dan posttest.Pretest dilakukan sebelum model LKS diujicobakan sedangkan posttest dilakukan setelah model LKS dengan teknik copy the master diujicobakan. Berdasarkan hasil pretest siswa, nilai yang diperoleh belum mencapai KKM. Setelah model LKS dengan teknik copy the master diujicobakan dan dilakukan posttest menulis karangan eksposisi, nilai yang diperoleh mengalami peningkatan. Rata-rata siswa memperoleh nilai di atas KKM (nilai tertinggi dari posttest adalah 95).

Keefektivan model LKS dengan teknik copy the master juga dapat dilihat dari perhitungan nilai siswa dengan menggunakan skala Likert. Berdasarkan hasil perhitungan dengan rumus Likert diperoleh hasil 85,25 \% sehingga penggunaan model LKS dengan teknik copy the master pada materi menulis karangan eksposisi efektif.

Berdasarkan kesimpulan yang diperoleh dari hasil penelitian, maka dikemukakan saransaran sebagai berikut.

1. Guru bahasa dan sastra Indonesia kelas X SMK Kartika 1-2 Padang dapat menggunakan model LKS dengan teknik copy the master pada materi menulis karangan eksposisi sebagai media alternatif dalam pembelajaran Bahasa Indonesia. Siswa kelas X SMK Kartika 1-2 Padang dapat menggunakan model LKS dengan teknik copy the master sebagai alternatif buku pegangan tambahan agar bisa lebih memahami materi mengenai materi menulis karangan eksposisi.

2. Peneliti sendiri dapat menggunakan model LKS dengan teknik copy the master pada materi menulis karanagan eksposisi sebagai bahan kajian akademik.

Catatan: artikel ini disusun berdasarkan hasil penelitian untuk penulisan skripsi penulis dengan Pembimbing I Prof. Dr. Syahrul R.,, M.Pd. dan pembimbing II Ena Noveria, M.Pd.

\section{Daftar Rujukan}

Arikunto, S. (2005). Manajemen Penelitian. Jakarta: Rineka Cipta.

Barry, Daniel. J. (2010). Expository Text and Elementary Student Achievement on standardized Tests. Northents Michigan University. Submitted In Partial Fulfillment of THE Requirements For The Degree Of Education Specialist In Education At Northern Michigan University April 15.

Cihak, David F. (2011). Improving Expository Writing Skills with Explicit and Strategy Instructional Methods in Inclusive Middle School Classrooms. Kristin Castle University ofTennessee, Knoxville. International Journal Of Special Education Vol 26, No: 3.

Darmodjo, H dan Kaligis, J.R. (1992).Pendidikan IPA II. Jakarta: Departemen Pendidikan ～dan Kebudayaan.

Direktorat Jenderal Manejemen Pendidikan Dasar dan Menengah.(2008). Panduan Pengembangan Bahan Ajar.Jakarta.: Depdiknas.

Gay, dkk. (2009). Educational Reserch: Competencies for Analysis and Aplication ( $9^{\text {th }}$ ed.) $\quad$ New Jersey: Pearson Education Inc. 
Harlina, Tika. (2017).Pengaruh Penggunaan Teknik Copy the Master Terhadap Keterampilan Menulis Teks Biografi Siswa Kelas X SMAN 1 Painan Pesisir Selatan. Jurnal Pendidikan Bahasa dan Sastra Indonesia, Vol. 6 No. 2 September 2017; Seri E 383-387

Hidayah, Isti, dkk. (2007). Workshop Pendidikan Matematika 2. Semarang : Jurusan Matematika UNES.

Kemendiknas.(2012). Juknis Penyusunan Bahan Ajar SMA. Jakarta: Direktorat Pembinaan SMA.

Lubis, Mina Syanti. (2015). Pengembangan Modul Pembelajaran Bahasa Indonesia Berbantuan Peta Pikiran Pada Materi Menulis Makalah Siswa Kelas XI SMA/MA. Jurnal Bahasa, Sastra dan Pembelajaran Volume 2 Nomor 1, Februari 2015.

Maharimin, Ismail. (2009). Menulis Secara Populer. Jakarta: Dunia Pustaka Jaya.

Prastowo, A. (2011). Panduan Membuat Bahan Ajar Inovatif: Menciptakan Metode Pembelajaran yang Menarik dan Menyenangkan. Yogyakarta: DIVA Press.

Rochmad. (2011). Model Pengembangan Perangkat Pembelajaran Matematika. Semarang : UNNES.

Rohimat, Aep (2013). Penerapan Teknik Copy The Master Dalam Pembelajaran Menulis Karangan Persuasi Pada Siswa Kelas X Sma Pasundan 7 Bandung Tahun Ajaran 2012-2013 Jurusan Pendidikan Bahasa dan Sastra Indonesia FPBS, Universitas Pendidikan Indonesia.

Rosyidah, Syahrul R, dan Ermanto. (2013). Peningkatan keterampilan menulis cerita memalui teknik tiru model siswa kelas III SD Negeri 200208 Padang Sidempuan. Jurnal Bahasa, Sastra danPembelajaran Volume 1 Nomor 3, Oktober 2013.

Santoso, P. dkk. (2003). Materi dan Pembelajaran Bahasa Indonesia SD. Jakarta : Pusat Penerbit UT

Sukardi.(2008). Evaluasi Pendidikan: Prinsip dan Operasionalnya. Jakarta: Bumi Aksara.

Sudjana dan Riva'i. (2010). Media Pengajaran. Bandung: Sinar Baru Algesindo

Trianto.(2012). Mendesain Model Pembelajaran Inovatif-Progresif.Jakarta: Kencana Prenada Media Grup

Trianto.(2012). Model Pembelajaran Terpadu: Konsep, Strategi, dan Implementasinya dalam Kurikulum Tingkat Satuan Pendidikan (KTSP). Jakarta: Bumi Aksara.

Zurita, Isesma. (2017). Pengaruh teknik copy the master menulis teks prosedur siswa Kelas VII MTsN Lubuk Buaya Padang. Jurnal Pendidikan Bahasa dan Sastra Indonesia, Vol. 6 No. 2 September 2017; Seri B 167-174 